\title{
Characterization and growth response to temperature and salinity of psychrophilic, halotolerant Chlamydomonas sp. ARC isolated from Chukchi Sea ice
}

\author{
Brian Eddie $^{1}$, Christopher Krembs ${ }^{2}$, Susanne Neuer ${ }^{1, *}$ \\ ${ }^{1}$ School of Life Sciences, Arizona State University, Tempe, Arizona 85287, USA \\ ${ }^{2}$ Applied Physics Laboratory, University of Washington, Seattle, Washington 98195, USA
}

\begin{abstract}
Sea ice provides a habitat for a diverse community of microorganisms, which comprise a substantial portion of primary production in ice-covered seas. Organisms immured in sea ice have to withstand strong changes in temperature and salinity. We report on the growth rate response to salinity and temperature of the chlorophyte Chlamydomonas sp. ARC, isolated from land-fast sea ice in the Chukchi Sea, Alaska. We found it to be a euryhaline psychrophile capable of growth at temperatures as low as $-5^{\circ} \mathrm{C}$ and at salinities from 2.5 to $100 \%$. The maximum growth rate of $0.41 \mathrm{~d}^{-1}$ $( \pm 0.027)$ was found at $5^{\circ} \mathrm{C}$ and a salinity of $30 \%$. The salinity growth range of this organism indicates that it is well adapted to the variable salinity environment associated with brine channels in sea ice, as well as the hypotonic conditions associated with melting ice. Based upon morphology and molecular phylogenetic reconstructions using the $18 \mathrm{~S}$ ribosomal ribonucleic acid (rRNA) gene and the ribulose 1,5-bisphosphate carboxylase/oxygenase large subunit ( $r b c L$ ) gene, this Arctic Chlamydomonas falls into a distinct clade containing other as yet unassigned psychrophilic Chlamydomonas strains isolated from Arctic and Antarctic environments, pointing to a bi-polar distribution of this clade. It is also very closely related to the brackish water mesophile Chlamydomonas kuwadae Gerloff, and is capable of growth above the psychrophilic range in low-salinity medium, indicating that it may represent an intermediate between mesophilic and psychrophilic lifestyles.
\end{abstract}

KEY WORDS: Chlamydomonas · Chlorophyta · Arctic sea ice · Chukchi Sea · Psychrophile • Euryhaline $\cdot$ Phylogeny

\section{INTRODUCTION}

Sea ice covers 3 to $6 \%$ of the Earth's surface, making it one of the planet's largest single biomes, with a maximal extent of 16 million $\mathrm{km}^{2}$ in the northern hemisphere and 19 million $\mathrm{km}^{2}$ in the southern hemisphere (Comiso 2003). Sea ice provides a diverse habitat for a wide variety of photo- and heterotrophic organisms, which can attach themselves to or become immured in the ice substrate (Horner 1985, Lizotte 2003). In seasonally ice-covered seas, ice algae generally dominate primary production during the ice-covered season, and contribute significantly to annual primary production (reviewed in Arrigo 2003).
Sea ice is a habitat characterized by strong changes in salinity. Initially, when seawater freezes, constituent ions are concentrated into so-called brine channels and pockets, which may reach salinities of up to $225 \%$ (Krembs et al. 2000). These brines may also differ from the original seawater in ionic composition due to differential precipitation of salts (Assur 1958). As sea ice ages, bulk salinity tends to decrease because of brine drainage. When ice warms in the spring, the brine pockets connect and become channels, flushing even more salt out of the ice (Eicken 2003). Eventually, when the low-salinity ice melts, it creates a layer of fresher water, exposing the organisms from melting ice to hypotonic conditions, indicating that, in addition to cold 
temperatures, ice algae growing in the brine channels need to be tolerant of widely varying salinities.

In physiological studies testing the adaptation of Antarctic ice algae to low temperature and high salinity, Bartsch (1989) found that cell division was observed at temperatures as cold as $-5.5^{\circ} \mathrm{C}$ and a salinity of $90 \%$. Aletsee \& Jahnke (1992) reported growth of the marine diatoms Nitzschia frigida Grunow and Thalassiosira antarctica Comber at temperatures as low as -8 and $-6^{\circ} \mathrm{C}$ and at salinities of 145 and $109 \%$, respectively. In general, sea-ice diatoms are often euryhaline and thrive in conditions from 10 to $60 \%$ (Grant \& Horner 1976).

Diatoms have been the focus of most studies on seaice algae, because they are considered the most abundant phototrophs in sea ice (Horner 1985, Lizotte 2003). Green algae are usually a relatively minor component, but the chlorophyte Chlamydomonas spp. has been found repeatedly in Arctic sea ice (see 'Discussion'). Chlamydomonas species may play a disproportionably large role in the initial colonization of sea ice. Weissenberger (1998) found Chlamydomonas sp. to dominate newly formed ice for the first 3 mo in a tank experiment inoculated with an enrichment culture from sea-ice brine. Despite their ubiquity in Arctic sea ice, most research into psychrophilic green algae has focused on snow algae (e.g. Hoham et al. 2002) or Antarctic strains (Morgan et al. 1998, Liu et al. 2006).

We report for the first time on the growth response of a strain of Chlamydomonas sp. isolated from Arctic land-fast sea ice to variations in both salinity and temperature, encompassing nearly the entire growth range of this organism. We also report on the major pigments present in this strain. Furthermore, we use morphology and phylogenetic reconstructions based on the $18 \mathrm{~S}$ ribosomal ribonucleic acid (rRNA) gene and the ribulose 1,5-bisphosphate carboxylase/ oxygenase large subunit $(r b c L)$ gene to determine its relationship to psychrophilic chlorophytes described from other cold habitats.

\section{MATERIALS AND METHODS}

Isolation and culture conditions. Chlamydomonas sp. ARC was isolated from an enrichment culture, where it was growing in close affiliation with a diatom later identified as Melosira arctica Dickie var. krembsii (Kaczmarska \& Jahn 2006). Cold-adapted algae were enriched from a bottom sample of a $1.5 \mathrm{~m}$ sedimentfree Chukchi Sea ice core that was collected in June 2001, from a snow-free location offshore of Barrow, Alaska $\left(71^{\circ} 20^{\prime} \mathrm{N}, 156^{\circ} 40^{\prime} \mathrm{W}\right)$. The bottom $10 \mathrm{~cm}$ was melted at $0^{\circ} \mathrm{C}$ in pre-filtered seawater at a volume ratio of 3:1 to avoid osmotic shock. Aliquots in $12 \mathrm{ml}$ glass vials were incubated at temperatures ranging from -5 to $-20^{\circ} \mathrm{C}$ in light starting at $50 \mu \mathrm{mol}$ photons $\mathrm{m}^{-2} \mathrm{~s}^{-1}$ and decreasing to $0 \mu \mathrm{mol}$ photons $\mathrm{m}^{-2} \mathrm{~s}^{-1}$ in 4 steps over the course of a week. After $1 \mathrm{wk}$ in the dark, light was brought back up to $50 \mu \mathrm{mol}$ photons $\mathrm{m}^{-2} \mathrm{~s}^{-1}$ in 4 steps over a week, and cultures were incubated at $4^{\circ} \mathrm{C}$ for 2 more weeks to allow autotrophic organisms to grow. A sample of the enrichment was sent to Arizona State University (ASU), where both $M$. arctica and Chlamydomonas sp. strain ARC were isolated after plating the enrichment culture on marine agar plates. Both strains are currently in culture in S. Neuer's laboratory at ASU.

Growth rate experiments. Cultures of Chlamydomonas sp. ARC were grown in artificial seawater medium with salinity adjusted to vary between 2.5 and $150 \%$, to approximate the wide range of salinities that may be encountered by sea-ice organisms. The artificial seawater medium was prepared with Instant Ocean salt mixtures (Aquarium Systems) and enriched with $\mathrm{NO}_{3}{ }^{-}$and $\mathrm{PO}_{4}{ }^{3-}$, to a final concentration of $500 \mu \mathrm{M}$ nitrate and $35 \mu \mathrm{M}$ phosphate, and supplemented with trace metals and vitamins (Neuer 1992). Media were autoclaved for $10 \mathrm{~min}$ at $121^{\circ} \mathrm{C}$. Batch cultures were grown in $250 \mathrm{ml}$ Erlenmeyer flasks, under continuous white light at a photon flux of 11 to $13 \mu \mathrm{mol}$ photons $\mathrm{m}^{-2} \mathrm{~s}^{-1}$ (measured with a LICOR-250 light meter). This light level was chosen to simulate light conditions at the bottom of sea ice in spring, which, depending upon temperature, snow cover and immured sediment and biota, can be $<1 \%$ of the incident light (Arrigo 2003). We determined growth rates of cultures of Chlamydomonas sp. for a range of salinity and temperature conditions, with salinity varying from 10 to $90 \%$ and temperature from -10 to $20^{\circ} \mathrm{C}$. Cultures were grown at salinities outside of this range in preliminary experiments to determine the nominal salinity range. Cultures at temperatures between 0 and $20^{\circ} \mathrm{C}$ were maintained in triplicate in a Shel-Labs Low Temperature/B.O.D. Incubator Model 2005 (Sheldon Manufacturing). For -5 and $-10^{\circ} \mathrm{C}$ experiments, a modified Sears Coldspot freezer compartment was used with photon flux averaging $11 \mu \mathrm{mol}$ photons $\mathrm{m}^{-2} \mathrm{~s}^{-1}$. Due to space limitations only 1 replicate per salinity level could be grown at $-5^{\circ} \mathrm{C}$, and the experiment was repeated 3 times. For experiments conducted at $-10^{\circ} \mathrm{C}$, cultures were inoculated into small glass vials containing $6 \mathrm{ml}$ of $30 \%$ medium. At each of the 4 weekly samplings, one of the experimental vials was thawed and sampled. After $4 \mathrm{wk}$, live cells were no longer observed and the experiment was discontinued.

Growth rates were determined over the course of 2 to $4 \mathrm{wk}$ using cell counts obtained by epifluorescence microscopy. Samples of 0.5 to $10 \mathrm{ml}$ were vacuum filtered onto $0.22 \mu \mathrm{m}$ polycarbonate membrane filters, 
using autoclaved seawater medium to dilute samples of $<3 \mathrm{ml}$ to ensure even distribution of cells. The volume filtered was adjusted to give a statistically significant number of cells (30 to 300) when counting 10 to 30 fields. The filters were embedded in immersion oil, mounted on slides, and stored at $-15^{\circ} \mathrm{C}$ until analysis. The slides were examined under blue light excitation using a Zeiss Axio A.1, with a $100 \times$ objective. Cells displaying red auto-fluorescence were counted as live cells; cells with no chlorophyll fluorescence were not counted. The natural logarithm of cell number $(N)$ was plotted against time $(t)$, and the instantaneous growth rate $\left(\mu, \mathrm{d}^{-1}\right)$ was calculated for the duration of exponential growth by the formula:

$$
\mu=\operatorname{Ln}\left(N_{t} N_{0}^{-1}\right) t^{-1}
$$

Light and electron microscopy. Differential interference contrast (DIC) photomicrographs of wet mounts from mid-exponential phase cultures were taken with an Olympus C7070 digital camera (Olympus). Cell dimensions were measured in pixels, and converted to micrometers by calibrating pixel size with a micrometer slide.

For electron microscopy, a mid-exponential phase culture grown at $5{ }^{\circ} \mathrm{C}$ and $30 \%$ was fixed in $3 \%(\mathrm{v} / \mathrm{v})$ glutaraldehyde in $30 \%$ seawater (Sigma), the cells were pelleted in a centrifuge and embedded in $1 \%$ $(\mathrm{w} / \mathrm{v})$ ion-agar. Secondary fixation was $2 \mathrm{~h}$ with $1.5 \%$ $(\mathrm{w} / \mathrm{v})$ osmium tetroxide in seawater, and stained en bloc with $0.5 \%(\mathrm{w} / \mathrm{v})$ uranyl acetate. Agar blocks were then dehydrated in acetone and infiltrated with Spurr's resin in $20 \%$ increments. Cured blocks were thin sectioned at 70 to $80 \mathrm{~nm}$ with a Leica Ultracut-R microtome and viewed at $80 \mathrm{kV}$ using a Philips-FEI CM12S microscope.

Molecular analysis. DNA was extracted from Chlamydomonas sp. ARC, C. raudensis Ettl UWO 241, and Dunaliella tertiolecta Butcher CCMP 1320 using a plant DNA extraction kit (MoBio). An 1800 bp region of the nuclear 18S rRNA gene and a $\sim 1400 \mathrm{bp}$ fragment of the $r b c L$ gene were amplified using the polymerase chain reaction (PCR) with primer sets EUK $\mathrm{A} / \mathrm{B}, \mathrm{SN} 1 / 2$, and $r b c L \mathrm{~F} / \mathrm{R}$ (Table 1) in separate reactions. PCR products were purified using a QIAquik PCR cleanup kit (QUIAGEN Sciences). For PCR of the 18s rRNA gene, the thermocycler was programmed with a 5 min hot start at $94^{\circ} \mathrm{C}$, followed by $1 \mathrm{~min}$ at $80^{\circ} \mathrm{C}$ and 30 cycles of 95,60 , and $72^{\circ} \mathrm{C}$ for 1 min each, with a 9 min final elongation at $72^{\circ} \mathrm{C}$. For the $r b c L$ gene amplification, the annealing temperature was lowered to $45^{\circ} \mathrm{C}$. DNA extracts and PCR products were detected and quantified on standard agarose gels.

Amplified regions were sequenced commercially using all 6 primers. DNA sequences were aligned using ClustalW in MEGA 3.1 (Kumar et al. 2004) to generate a combined 18S rRNA sequence of $1689 \mathrm{bp}$ length and a $r b c L$ sequence of $1349 \mathrm{bp}$ length. The $18 \mathrm{~S}$ rRNA sequences of other cultured organisms (Table 2) were selected on the basis of having high similarity to the 18S rRNA gene of Chlamydomonas sp. ARC, using the basic local alignment search tool (BLAST) to search GenBank. Sequences from other organisms were included to produce phylogenetic trees with an overall topology similar to the Chlamydomonas phylogeny shown in Pröschold et al. (2001). The phylogenetic tree based on the rbcL gene sequences included the 10 organisms in the $18 \mathrm{~S}$ phylogenetic tree that also had rbcL sequences available in GenBank. In addition, we included C. kuwadae because of its close match to Chlamydomonas sp. ARC.

Phylogenetic trees of $18 \mathrm{~S}$ and $r b c L$ sequences were inferred by maximum parsimony (MP) and minimum evolution (ME) methods using MEGA 3.1 (Kumar et al. 2004). MP phylogenies were inferred using the closeneighbor-interchange algorithm with search level 2 (Nei \& Kumar 2000), with gaps and absent ends of short sequences treated as missing data. Initial trees were made by random addition (100 reps). ME phylogenies were inferred using the Kimura 2-parameter model with Gamma shape parameters of 0.61 and 1.67 for $18 \mathrm{~S}$ and $r b c L$, respectively, taken from Liu et al. (2006). Gaps were deleted pairwise. Confidence of

Table 1. Oligonucleotide primers used for PCR amplification and sequencing. Sequences of fragments generated by EUK A and EUK B were aligned with sequences of fragments generated by SN1 and SN2, to give a total of 1689 usable bases

\begin{tabular}{|lll|}
\hline Primer & Sequence & Binding site (positions) \\
\hline SN1 & AATTCCAGCTCCAATAGC & Saccharomyces cerevisiae, 18S, 580-597 \\
SN2 & AAAGAGCTCTCAATCTG & Saccharomyces cerevisiae, 18S, 1252-1236 \\
EUK A ${ }^{\mathrm{a}}$ & AACCTGGTTGATCTGCCAGT & Saccharomyces cerevisiae, 18S, 1-21 \\
EUK B $^{\mathrm{a}}$ & TGATCCTTCTGCAGGTTCACCTAC & Saccharomyces cerevisiae, 18S, 1795-1772 \\
$r b c L(\mathrm{~F})^{\mathrm{b}}$ & ATGGTTCACAAACAGAAAC & Chlorella ellipsoidea, rbcL, 1-20 \\
$r b c L(\mathrm{R})^{\mathrm{b}}$ & TTGTCAATAGTATCAAATTC & Chlorella ellipsoidea, rbcL, 1421-1402 \\
${ }^{\mathrm{a} M e d l i n}$ et al. (1988) & & \\
${ }^{\mathrm{b}}$ Nozaki et al. (1995) & & \\
\hline
\end{tabular}


Table 2. Strain name, accession number, and habitat information of the organisms included in the phylogenetic trees (Figs. $3 \& 4$ ). Sequences listed as unpublished may be part of manuscripts in preparation. SAG: Sammlung von Algenkulturen der Universität Göttingen; CCMP: Provasoli-Guillard National Center for Culture of Marine Phytoplankton; UTEX: Culture Collection of Algae at the University of Texas at Austin; CGC CC: Chlamydomonas Genetics Center Culture Collection; MBIC: Marine Biotechnology Institute Culture Collection; NIES: National Institute for Environmental studies

\begin{tabular}{|c|c|c|c|c|}
\hline \multirow[t]{2}{*}{ Strain } & \multicolumn{2}{|c|}{ — Accession no.— } & \multirow{2}{*}{$\begin{array}{l}\text { Habitat, location } \\
\text { of isolation }\end{array}$} & \multirow[t]{2}{*}{ Source } \\
\hline & $18 \mathrm{~S}$ & rbcL & & \\
\hline Chlamydomonas sp. ARC & EF537906 & EF537908 & First year sea ice, Barrow, AK, USA & Present paper \\
\hline $\begin{array}{l}\text { Carteria crucifera } \\
\text { NIES- } 421\end{array}$ & & D63431 & Kept in freshwater, $20^{\circ} \mathrm{C}^{\mathrm{a}}$ & Nozaki et al. (1995) \\
\hline $\begin{array}{l}\text { Chlamydomonas kuwadae } \\
\text { NIES-968 }\end{array}$ & & AB084334 & $\begin{array}{l}\text { Lake Nojiri, Japan, kept in } \\
\text { freshwater, } 20^{\circ} \mathrm{C}^{\mathrm{a}}\end{array}$ & Nozaki et al. (2002) \\
\hline $\begin{array}{l}\text { Chlamydomonas monadina } \\
\text { SAG } 31.72\end{array}$ & U57694 & & $\begin{array}{l}\text { Yellowwood fishponds, } \\
\text { Bloomington, IN, USA }{ }^{\text {a }}\end{array}$ & Buchheim et al. (1996) \\
\hline $\begin{array}{l}\text { Chlamydomonas nivalis } \\
\text { UTEX LB1969 }\end{array}$ & U57696 & & Snow, Cascade Mountains ${ }^{a}$ & Buchheim et al. (1996) \\
\hline $\begin{array}{l}\text { Chlamydomonas pulsatilla } \\
\text { CCCryo 038-99 }\end{array}$ & AF514404 & & $\begin{array}{l}\text { Snow, Spitsbergen, Norway, } \\
\text { near shore }{ }^{\mathrm{b}}\end{array}$ & Leya (2004) \\
\hline $\begin{array}{l}\text { Chlamydomonas pulsatilla } \\
\text { UTEX 410/ CCAP 11/44 }\end{array}$ & DQ009748 & AB007322 & $\begin{array}{l}\text { Marine, Tvärminne, Finland, kept } \\
\text { in freshwater medium at UTEX }\end{array}$ & $\begin{array}{l}\text { 18S: (unpubl.); } \\
\text { rbcL: (unpubl.) }\end{array}$ \\
\hline $\begin{array}{l}\text { Chlamydomonas raudensis } \\
\text { CCMP 1619, UWO } 241\end{array}$ & AJ781313 & DQ196177 & Lake Bonney, Antarctica ${ }^{\mathrm{b}}$ & Pocock et al. (2004) \\
\hline $\begin{array}{l}\text { Chlamydomonas reginae } \\
\text { SAG } 17.89\end{array}$ & DQ009749 & & $\begin{array}{l}\text { Marine sand in the intertidal, } \\
\text { Roscoff, France }{ }^{\mathrm{a}}\end{array}$ & Unpubl. \\
\hline $\begin{array}{l}\text { Chlamydomonas reinhardtii } \\
\text { 18S: CGC CC-1952 } \\
\text { rbcL: CGC CC-125 }\end{array}$ & AY665727 & J01399 & $\begin{array}{l}\text { CC-1952: MN, USA }{ }^{\mathrm{b}} \\
\text { CC-125: MA, USA }\end{array}$ & $\begin{array}{l}\text { 18S: (unpubl.); } \\
\text { rbcL: Dron et al. (1982) }\end{array}$ \\
\hline $\begin{array}{l}\text { Chlamydomonas sp. } \\
\text { Antarctic 2E9 }\end{array}$ & AB001374 & & Not reported & Unpubl. \\
\hline $\begin{array}{l}\text { Chlamydomonas sp. } \\
\text { CCCryo 002b-99 }\end{array}$ & AF514398 & & $\begin{array}{l}\text { Snow, Spitsbergen, Norway, } \\
\text { near shore }{ }^{b}\end{array}$ & Leya (2004) \\
\hline $\begin{array}{l}\text { Chlamydomonas sp. } \\
\text { CCMP } 233\end{array}$ & DQ009753 & & Pismo Beach, CA, USA ${ }^{a}$ & Unpubl. \\
\hline $\begin{array}{l}\text { Chlamydomonas sp. } \\
\text { ICE-W }\end{array}$ & AY731083 & AY731087 & Antarctic sea ice ${ }^{b}$ & Liu et al. (2006) \\
\hline $\begin{array}{l}\text { Chlamydomonas sp. } \\
\text { ICE-L }\end{array}$ & AY731082 & AY731086 & Antarctic sea ice ${ }^{b}$ & Liu et al. (2006) \\
\hline $\begin{array}{l}\text { Chlamydomonas sp. } \\
\text { MBIC } 10592\end{array}$ & AB058371 & & Seawater, Kii Peninsula, Japan ${ }^{a}$ & Unpubl., MBIC \\
\hline $\begin{array}{l}\text { Chlamydomonas subcaudata } \\
\text { SAG } 12.87\end{array}$ & AJ781310 & & Freshwater, Hokkaido, Japan ${ }^{\mathrm{b}}$ & Pocock et al. (2004) \\
\hline $\begin{array}{l}\text { Chlamydomonas uva-maris } \\
\text { SAG } 19.89\end{array}$ & DQ009757 & & Brackish water, Norfolk, England ${ }^{a}$ & Unpubl. \\
\hline $\begin{array}{l}\text { Chloromonas nivalis } \\
\text { CU563D }\end{array}$ & & AF517088 & $\begin{array}{l}\text { Snow, Santa Catalina Mountains, } \\
\text { AZ, USA }{ }^{\mathrm{b}}\end{array}$ & Hoham et al. (2002) \\
\hline $\begin{array}{r}\text { Chloromonas rubrifilum } \\
\text { (C. clathrata) SAG } 3.85\end{array}$ & AJ410455 & & $\begin{array}{l}\text { Pond under ice, Dannenberg, } \\
\text { Germany }^{\mathrm{a}}\end{array}$ & Pröschold et al. (2001) \\
\hline $\begin{array}{l}\text { Chloromonas subdivisa } \\
\text { SAG } 67.72\end{array}$ & AF517096 & AF517080 & Alpine pond ${ }^{\mathrm{b}}$ & Hoham et al. (2002) \\
\hline $\begin{array}{l}\text { Dunaliella tertiolecta } \\
\text { CCMP } 1302\end{array}$ & & DQ313205 & Baja California, Mexico ${ }^{a}$ & Unpubl. \\
\hline $\begin{array}{l}\text { Dunaliella tertiolecta } \\
\text { CCMP } 1320\end{array}$ & EF537907 & & Unknown $^{\mathrm{a}}$ & Present paper \\
\hline $\begin{array}{l}\text { Pseudoscourfieldia marina } \\
\text { K-0017 }\end{array}$ & AJ132619 & & Marine, Oslofjord, Norway, $15^{\circ} \mathrm{C}^{\mathrm{a}}$ & Unpubl. \\
\hline
\end{tabular}


branching was inferred by bootstraps for all 4 trees, using 500 pseudoreplicates.

Pigment extraction and analysis. Cells from $75 \mathrm{ml}$ of a mid-exponential growth phase culture grown at $5^{\circ} \mathrm{C}$, $30 \%$, and a photon flux of $12 \mu \mathrm{mol}$ photons $\mathrm{m}^{-2} \mathrm{~s}^{-1}$ were pelleted by centrifugation, and pigments were extracted in $5 \mathrm{ml}$ of ice-cold $100 \%$ acetone for $1 \mathrm{~h}$. Cellular debris was removed by centrifugation, and the supernatant was filtered through a $0.22 \mu \mathrm{m}$ polycarbonate filter, concentrated by evaporation on ice with a stream of $\mathrm{N}_{2}$ gas, and stored at $-40^{\circ} \mathrm{C}$ until analysis. The pigments in the extract were separated by HPLC by injecting $50 \mu \mathrm{l}$ of the extract into a Spherisorb S10 ODS2 (10 $\mathrm{mm}$ by $250 \mathrm{~mm}$ ) semi-prep analytical column filled with reverse-phase silica gel (Waters) and run on a variable solvent gradient of water, methanol, and acetone at a pressure of approximately 38 bar (Soule et al. 2007). Pigments were detected continuously using an online photodiode array detector in the 405 to $665 \mathrm{~nm}$ range, identified by spectra, and quantified using published extinction coefficients (Köst 1988, Rowan 1989).

\section{RESULTS}

\section{Cell morphology}

We found Chlamydomonas sp. ARC to be a biflagellated unicellular chlorophyte, with cells 8 to $14 \mu \mathrm{m}$ long and 5 to $10 \mu \mathrm{m}$ wide (Fig. 1). Average cell diameter $( \pm \mathrm{SD})$ at $0^{\circ} \mathrm{C}$ and $30 \%$ was $8.4 \mu \mathrm{m}( \pm 1.2)$, increasing to $10.6 \mu \mathrm{m}( \pm 1.6)$ and $9.3 \mu \mathrm{m}( \pm 0.90)$ at 10 and $90 \%$, respectively. At $10^{\circ} \mathrm{C}$ and $10 \%$, cell diameter decreased to $9.5( \pm 1.1)$. Analysis of variance (ANOVA) indicated that differences in cell diameter between the $0{ }^{\circ} \mathrm{C} / 30 \%$ treatment and the other treatments listed above were statistically significant $(p<0.05)$. Flagella were 1 to 1.5 times the length of the cell and emerged from a papilla that is round from one angle and flat from another (Fig. 1B-D, G). It had a single, parietal, cup-shaped chloroplast that filled the posterior half of the cell and was cupped around a slightly anterior nucleus (Fig. 1A,B,E). The cells displayed 2 contractile vacuoles when grown at $10 \%$ (Fig. 1B) and $20 \%$, but, at $30 \%$, all that remained was the tubular spongiome complexes (Fig. 1A,D). Cells contained a round to slightly oblong pyrenoid, located in the basal portion of the chloroplast. The pyrenoid was surrounded by thick starch plates and penetrated by thylakoid membranes (Fig. 1E), occasionally giving it a very faint striped appearance in the light microscope (Fig. 1A). Iodine staining revealed visibly stained starch only around the pyrenoid. Cells also had a single oblong eyespot approximately 1 to $1.5 \mu \mathrm{m}$ long located in the middle third of the cell between the thylakoid membranes and the cell wall (Fig. 1A,F,H). During asexual reproduction, sporangia developed with 4 zoospores (Fig. 1E) that were subsequently released. Flagella were absent during mitosis in the sporangia, but formed before the cells were released (Fig. 1D-F). The cells in the sporangia were surrounded by an extracellular matrix and sometimes clumped into aggregates of $>50$ cells. Sexual reproduction is unknown. Cells in nutrientdepleted cultures of up to 6 mo old did not form resting stages. Attempts to induce gamete production by $1 \mathrm{wk}$ $\mathrm{N}$-starvation followed by $48 \mathrm{~h}$ of darkness, as is known from Chlamydomonas reinhardtii (M. Sommerfeld, ASU, pers. comm.), were unsuccessful. The culture may have been monoclonal, accounting for the lack of gamete production.

\section{Growth response to salinity and temperature}

Chlamydomonas sp. ARC is a psychrophile with highest instantaneous growth rates of $0.41 \mathrm{~d}^{-1}( \pm 0.03)$ attained in nutrient-replete medium at $5^{\circ} \mathrm{C}$ and a salinity of $30 \%$ (Fig. 2, Table 3). The organism displayed tolerance to salinities from 10 to $75 \%$, at temperatures between 0 and $10^{\circ} \mathrm{C}$, with growth rates $>0.2 \mathrm{~d}^{-1}(>50 \%$ of growth rate maximum), indicating the euryhaline nature of the strain at these temperatures. Growth rates in $10 \%$ medium remained close to maximum from 0 to $20^{\circ} \mathrm{C}$. Growth was still observed at 2.5 and $100 \%$, but not at $150 \%$ (data not shown). At $20^{\circ} \mathrm{C}$, the salinity range was severely restricted, with growth in all 3 replicates at $10 \%$, in only 1 of 3 replicates at $20 \%$, and no growth at $\geq 30 \%$. Salinity and temperature showed clear interactive effects; high salinities decreased the maximum temperature at which the organism could grow, and low salinities (10 and 20\%o) enabled faster growth at warmer temperatures.

At $-5^{\circ} \mathrm{C}$, growth was inconsistent, with only 1 replicate growing at each salinity between 30 and $90 \%$. The $-5^{\circ} \mathrm{C}$ growth experiments froze only intermittently at $30 \%$. Of these $30 \%$ liquid samples, temperature excursions from -5 to $-7^{\circ} \mathrm{C}$ induced ice formation, but no detrimental effects on cell morphology were detected microscopically. Motile cells were observed in the culture immediately following melting. Cultures grown at $-5^{\circ} \mathrm{C}$ and salinities of 50,75 , and $90 \%$ remained liquid throughout the experiment. Cells survived $-20^{\circ} \mathrm{C}$ with a corresponding brine salinity of $260 \%$ (Assur 1958) in the dark, but failed to grow at temperatures of $-10^{\circ} \mathrm{C}$.

\section{S rRNA sequence identity and phylogeny}

PCR amplification using primer set EUK A/B yielded a 1800 bp fragment. The sequence from Chlamy- 

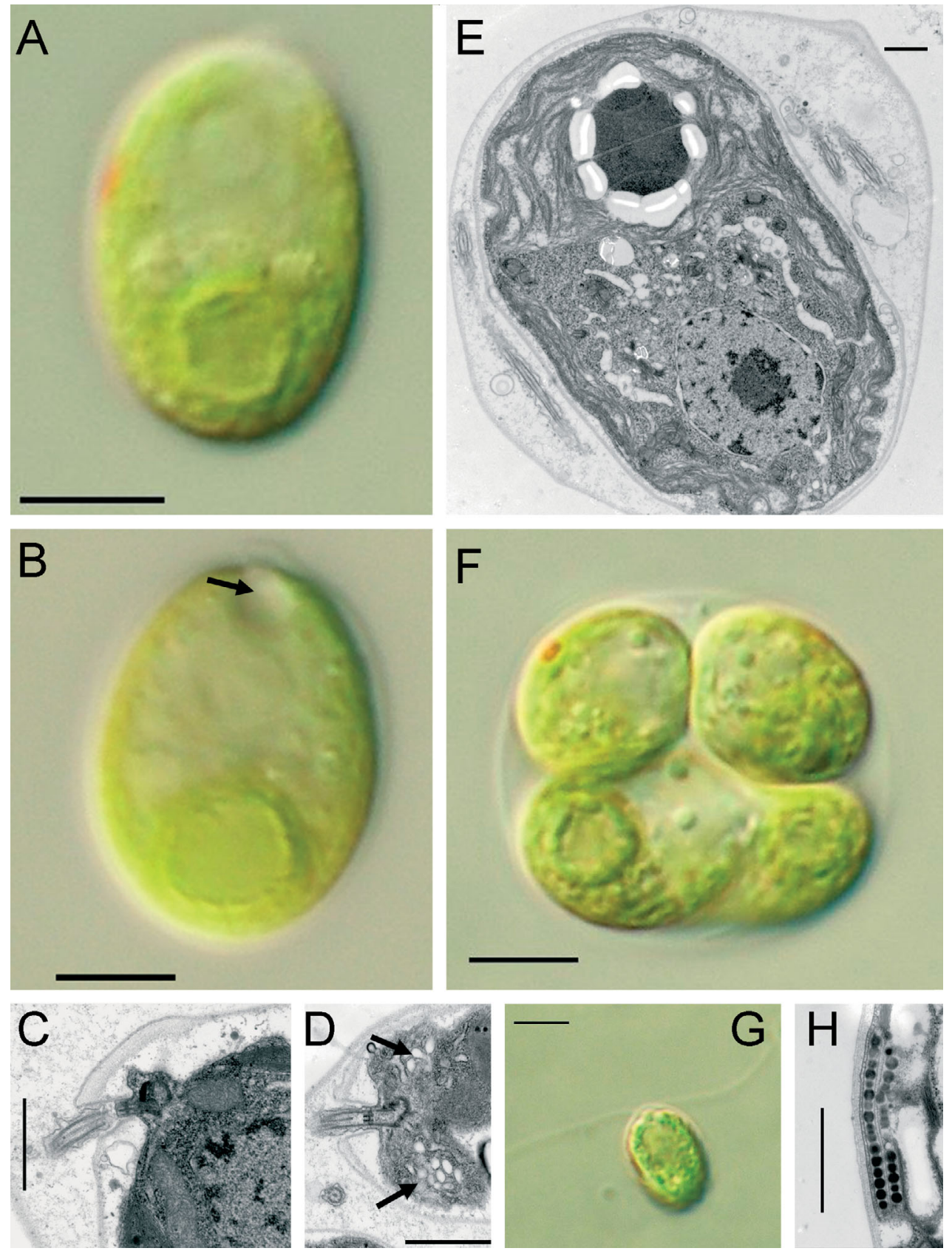

Fig. 1. Chlamydomonas sp. ARC. $(\mathrm{A}, \mathrm{B}, \mathrm{F}, \mathrm{G})$ Light microscope and $(\mathrm{C}, \mathrm{D}, \mathrm{E}, \mathrm{H})$ transmission electron micrographs of (A) unicell grown at $5^{\circ} \mathrm{C}$ and $30 \%$; (B) cell grown at $5^{\circ} \mathrm{C}$ and $10 \%$, showing contractile vacuole (arrow); (C) papilla and flagellar base; (D) zoospore prior to release, showing spongiome (arrows) and flagellar base; (E) zoospore prior to release, showing nucleus and thylakoid membranes penetrating the pyrenoid; (F) 4 cells after mitosis (note the common wall); (G) cell fixed in glutaraldehyde, showing 2 flagella; and $(H)$ eyespot with double layer of pigment globules. Scale bars $=5 \mu \mathrm{m}(\mathrm{A}, \mathrm{B}, \mathrm{F}, \mathrm{G})$ and $1 \mu \mathrm{m}(\mathrm{C}, \mathrm{D}, \mathrm{E}, \mathrm{H})$

domonas raudensis UWO 241 was used as a control for sequence accuracy and resulted in a sequence identical to the one in GenBank. The partial sequence (1689 bp) of the 18S rRNA gene allowed us to establish the phylogenetic relationship of Chlamydomonas sp. ARC to other strains of the genus Chlamydomonas (Fig. 3). We found no perfect match, but phylogeneti- cally, the strain falls within a tight clade formed by psychrophilic isolates from both poles, with strain CCCryo 002b-99 being the closest relative with a sequence similarity of $99.7 \%$ (difference of 4 bases out of 1689). Only 1 isolate has been assigned formally to a known species, strain CCCryo 038-99, which is named in GenBank as C. pulsatilla. This listing is incongruent with 


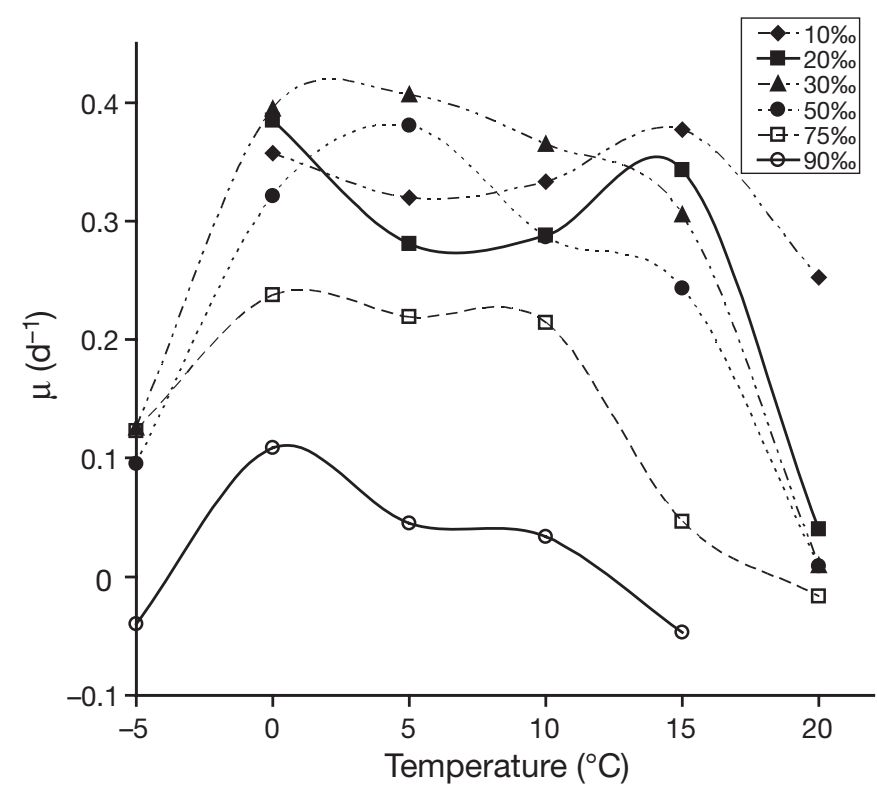

Fig. 2. Chlamydomonas sp. ARC. Growth rate $(\mu)$ as a function of temperature at different salinities. Results are from of a total of 11 individual experiments. Growth rates at 10 and $20 \%$ were obtained after the completion of the other 4 salinities

our phylogenetic analysis (Fig. 3) as C. pulsatilla CCCryo 038-99 has a similarity of only $96.4 \%$ to the strain C. pulsatilla Wollenweber UTEX 410, which has been in culture since 1950. Chlamydomonas sp. ARC falls into the Monadina subclade (Pröschold et al. 2001), and is part of a sister group to the lineage to which C. monadina Stein and Chloromonas subdivisa (Pascher et Jahoda) Gerloff et Ettl belong (Fig. 3). Furthermore, since Chlamydomonas sp. ARC is closely allied with Chlamydomonas sp. Antarctic 2E9 and Chloromonas subdivisa, it is basal to Clade A from Hoham et al. (2002), which contains a large number of psychrophilic Chloromonas strains.

PCR amplification of the $r b c L$ gene yielded a 1450 bp fragment, which, when sequenced and aligned, gave a $1349 \mathrm{bp}$ alignment. There were no perfect matches, but Chlamydomonas kuwadae
Gerloff NIES 968 resulted in the closest match, with a difference of $4 \mathrm{bp}$, all of which were silent mutations. Consequently, in a phylogenetic tree generated by the MP method, Chlamydomonas sp. ARC was most closely related to C. kuwadae, with Chlamydomonas spp. ICE-W and ICE-L forming a sister group (Fig. 4).

\section{Pigments}

HPLC of lipid soluble pigments showed the presence of chorophylls $a$ and $b$ (chls $a$ and $b$ ), as well as lutein, neoxanthin, lycopene and $\gamma$-carotene among the carotenoids. Chl $b$ was present at a molar ratio of $444 \mathrm{mmol} \mathrm{chl} b \mathrm{~mol}^{-1} \mathrm{chl}$ a. Lutein was the most abundant carotenoid (669 mmol mol ${ }^{-1} \mathrm{chl} \mathrm{a}$ ), and neoxanthin was present at $179 \mathrm{mmol} \mathrm{mol}^{-1} \mathrm{chl} \mathrm{a}$. Lycopene was present at a ratio of $44 \mathrm{mmol} \mathrm{mol}^{-1} \mathrm{chl} a$, and $\gamma$ carotene was present at $36 \mathrm{mmol} \mathrm{mol}^{-1} \mathrm{chl}$ a. $\beta$ carotene, if present, was below the detection level of approximately $25 \mathrm{mmol} \mathrm{mol}^{-1} \mathrm{chl}$ a.

\section{DISCUSSION}

We have demonstrated that Chlamydomonas sp. strain ARC is a psychrophile, displaying euryhaline characteristics at low temperature. Chlamydomonas sp. ARC is well adapted to the variable salinity typical of a sea-ice habitat and Arctic estuarine and coastal environments. Similar to sea-ice diatom taxa studied by Grant \& Horner (1976), our isolate is euryhaline, with a growth range from 2.5 to $100 \%$, and grows at $>75 \%$ of its maximum growth rate at salinities of 10 to $50 \%$. There is an interactive effect of temperature and salinity upon growth; in cultures grown at 10,30, and $90 \%$, the maximum temperatures at which we detected growth were 20,15 , and $10^{\circ} \mathrm{C}$, respectively. Furthermore, low temperatures seemed to mitigate the effects of high salinity; at $90 \%$ and $10^{\circ} \mathrm{C}$, the organism barely grew, but at $90 \%$ and $0^{\circ} \mathrm{C}$, the growth rate was

Table 3. Chlamydomonas sp. ARC. Mean instantaneous growth rates $\left(\mu \pm \mathrm{SD}_{i} \mathrm{n}=3\right.$ ), as a function of medium salinity and temperature

\begin{tabular}{|c|c|c|c|c|c|c|}
\hline & $10 \%$ & $20 \%$ & $30 \%$ & $50 \%$ & $75 \%$ & $90 \%$ \\
\hline$-5^{\circ} \mathrm{C}$ & & & $0.13^{\mathrm{a}}$ & $0.096^{\mathrm{a}}$ & $0.12^{\mathrm{a}}$ & $-0.04^{\mathrm{a}}$ \\
\hline $0^{\circ} \mathrm{C}$ & $0.36 \pm 0.028$ & $0.39 \pm 0.065$ & $0.40 \pm 0.025$ & $0.32 \pm 0.024$ & $0.24 \pm 0.024$ & $0.14 \pm 0.020$ \\
\hline $5^{\circ} \mathrm{C}$ & $0.32 \pm 0.0052$ & $0.28 \pm 0.0084$ & $0.41 \pm 0.027$ & $0.38 \pm 0.020$ & $0.22 \pm 0.032$ & $0.05 \pm 0.032$ \\
\hline $10^{\circ} \mathrm{C}$ & $0.33 \pm 0.0085$ & $0.29 \pm 0.051$ & $0.37 \pm 0.080$ & $0.29 \pm 0.078$ & $0.21 \pm 0.066$ & $0.03 \pm 0.026$ \\
\hline $15^{\circ} \mathrm{C}$ & $0.38 \pm 0.012$ & $0.34 \pm 0.019$ & $0.31 \pm 0.026$ & $0.24 \pm 0.017$ & $0.05 \pm 0.043$ & $-0.05 \pm 0.047$ \\
\hline $20^{\circ} \mathrm{C}$ & $0.25 \pm 0.062$ & $0.04 \pm 0.051^{b}$ & $0.01 \pm 0.025$ & $0.01 \pm 0.0019$ & $-0.02 \pm 0.0048$ & \\
\hline
\end{tabular}


Fig. 3. Chlamydomonas sp. phylogeny of with other related chlorophytes. Maximum parsimony consensus of 69 equally parsimonious trees, with a length of 808; bootstrap percentages of 500 replicates are shown. Phylogenetic analysis using a minimum evolution model confirmed the position of Chlamydomonas sp. ARC within a monophyletic clade of organisms isolated from polar environments (polar clade), with a bootstrap percentage of $100 \%$. Other relationships within the clade cannot be determined with the 18S rRNA gene

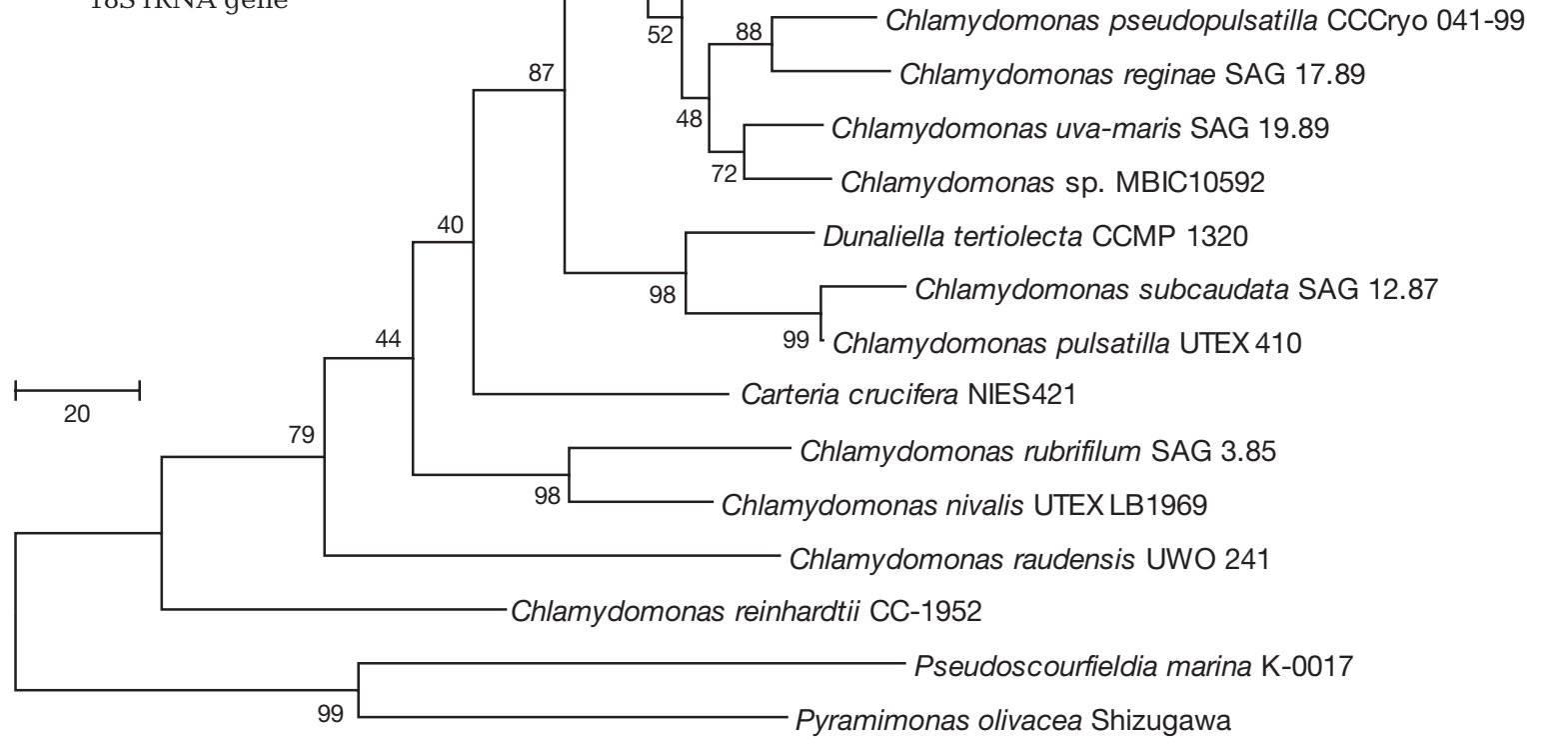

$0.14 \mathrm{~d}^{-1}( \pm 0.020)$. This agrees with findings reported by Aletsee \& Jahnke (1992) that Thalassiosira antarctica cultured in $73 \%$ medium would not grow at $6^{\circ} \mathrm{C}$, but grew at -4 and $-6^{\circ} \mathrm{C}$. The combined effect of temperature and salinity on growth rate has implications for understanding the physiological adaptations required for psychrophily in sea ice. In part due to the interactive effects of salinity and temperature, Clamydomonas sp. ARC blurs the line between a psychrophilic and psychrotolerant organism. By Morita's (1975) definition, a psychrophile is an organism that has an optimum growth temperature below $15^{\circ} \mathrm{C}$, a minimum temperature for growth at or below $0^{\circ} \mathrm{C}$, and a maximum temperature for growth below $20^{\circ} \mathrm{C}$. A psychrotolerant organism, on the other hand, has a maximum growth rate above $15^{\circ} \mathrm{C}$ and is capable of growth at $5^{\circ} \mathrm{C}$. At marine and sea-ice salinities, our strain is clearly a psychrophile, but at $10 \%$, it displays a growth pattern more consistent with a psychrotolerant organism.

The pigment analysis indicated an abundance of lutein and a curious absence of $\beta$-carotene and its derivatives zeaxanthin and antheraxanthin, pigments that are nearly always found in Chlorophyceae (Rowan 1989). Sea ice, particularly when under snow cover, attenuates light very quickly and lowers the need for photoprotective pigments. However, low temperature stress has been found to stimulate responses similar to high irradiance such as increased photoprotective pigments and decreased light-harvesting capability (Maxwell et al. 1994). Thus, it is interesting to find high levels of lutein, which can function as both a photoprotective pigment and a low-efficiency antenna pigment as part of light-harvesting Complex II, but no detectable zeaxanthin or antheraxanthin. These latter pigments are primarily photoprotective and increase lutein's nonphotochemical quenching ability (Demmig-Adams et al. 1999). Lutein was present at higher concentrations than in the shade-adapted sub-ice alga Chlamydomonas raudensis UWO 241 grown at $20 \mu \mathrm{mol}$ photons $\mathrm{m}^{-2} \mathrm{~s}^{-1}$ and $8^{\circ} \mathrm{C}\left(282 \pm 5.2 \mathrm{mmol} \mathrm{mol}^{-1} \mathrm{chl}\right.$ a) (Pocock et al. 2004), but was comparable to the mesophile $C$. reinhardtii grown at $150 \mu \mathrm{mol}$ photons $\mathrm{m}^{-2} \mathrm{~s}^{-1}$ and $16^{\circ} \mathrm{C}(747 \pm$ $105 \mathrm{mmol} \mathrm{mol}^{-1} \mathrm{chl} \mathrm{a)} \mathrm{(Morgan} \mathrm{et} \mathrm{al.} \mathrm{1998).} \mathrm{However,}$ 


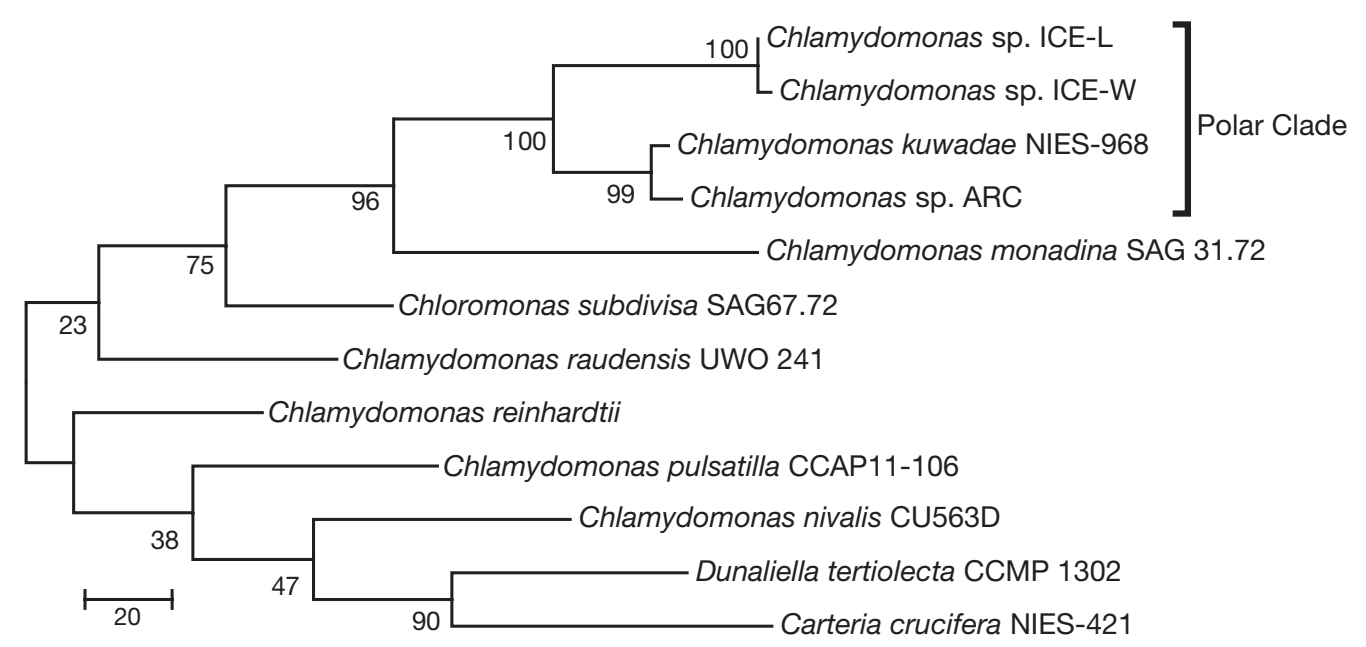

Fig. 4. Maximum parsimony consensus of the 2 most parsimonious rbcL phylogenies, with a length of 766. Bootstrap percentages of 500 replicates are shown, indicating strong support of the relationship between Chlamydomonas sp. ARC and the other members of the Monadina clade (Pröschold et al. 2001)

because we determined the pigment composition only under 1 set of conditions $\left(5^{\circ} \mathrm{C}, 30 \%\right.$, $12 \mu \mathrm{mol}$ photons $\mathrm{m}^{-2} \mathrm{~s}^{-1}$ ), it is difficult to ascertain the true function of these pigments in Chlamydomonas sp. ARC.

Chlamydomonas sp. ARC has an 18S rRNA sequence that is only slightly different from 5 other strains that form a clade of 6 closely related psychrophiles, which we have dubbed the 'polar clade', including the Antarctic marine strains Chlamydomonas sp. Antarctic 2E9 and Chlamydomonas spp. ICE-W and ICE-L, which were isolated from an ice floe near Antarctica (Liu et al. 2006). It is noteworthy that these 6 very closely related strains have been sequenced in 4 separate studies, and that 3 strains are Arctic and the other 3 are Antarctic (see Table 2), with no clear divergence between them. Also, The Provasoli-Guillard National Center for Culture of Marine Phytoplankton (http://ccmp.bigelow.org/) lists 7 unidentified and unsequenced Chlamydomonas spp. isolated from Arctic sea ice. This suggests a widespread group of psychrophilic marine Chlamydomonas that has not yet been described in any detail.

Compared to $18 \mathrm{~S}$ rRNA sequences, fewer strains of Chlamydomonas have had their rbcL genes sequenced. Based upon the available data, Chlamydomonas sp. ARC matched most closely the brackish water mesophile C. kuwadae Gerloff NIES-968 (Ettl 1976). The next 2 closest matches were the Antarctic strains Chlamydomonas ICE-W and ICE-L. This helps confirm the position of Chlamydomonas sp. ARC basal to the other 5 psychrophiles, and suggests that perhaps it represents an evolutionary intermediary between a mesophile and a psychrophile. However, the growth range of C. kuwadae Gerloff NIES-968, which is kept in freshwater medium at $20^{\circ} \mathrm{C}$ in the culture collection (see Table 2), has not been reported, leaving the option that this strain is capable of a psychrophilic lifestyle. In any case, psychrophily seems to be a rather transient trait among some chlorophytes (Hoham et al. 2002). There is at least one other example of a psychrophilic and mesophilic strain of the same species, namely $C$. raudensis Ettl (UWO 241) isolated from an ice-covered saline lake in Antarctica (Pocock et al. 2004, Szyszka et al. 2007). Thus, we hypothesize that this seemingly psychrophilic clade of Chlamydomonas simply exhibits a great amount of flexibility with respect to adaptation to a wide range of environmental conditions.

In terms of its morphology, Chlamydomonas sp. ARC does not match any of the reported species descriptions of Chlamydomonas shown in the phylogenetic trees in Figs. $3 \& 4$. C. monadina Stein has a semispherical or horseshoe-shaped pyrenoid; cells of $C$. monadina Stein are also about twice as large, and inhabit freshwaters (Ettl 1976). C. uva-maris Butcher has an ellipsoid, striped pyrenoid, and, while some striping is seen on the pyrenoid of Chlamydomonas sp. $\mathrm{ARC}$, it is quite faint and difficult to see using a light microscope. In cells of C. uva-maris Butcher, the striping is caused by the starch granules surrounding the pyrenoid (Ettl 1976), while in Chlamydomonas sp. $\mathrm{ARC}$, the striping seems to be mostly due to penetrations by the thylakoid membrane. C. kuwadae Gerloff is slightly different from Chlamydomonas sp. ARC morphologically, with a more horizontal and ellipsoid pyrenoid and a thinner basal portion of the chloroplast than Chlamydomonas sp. ARC. C. kuwadae Gerloff can also have 4 or 8 daughter cells, while only 4 were 
observed in Chlamydomonas sp. ARC. The morphological description of Chlamydomonas sp. ICE-L matches Chlamydomonas sp. ARC more closely, although it is slightly larger, with a smaller papilla.

Chlamydomonas sp. ARC cells grown at 10 and $20 \%$ have 2 contractile vacuoles, but, at $30 \%$, the vacuoles break down into tubular complexes (spongiomes). Hellebust et al. (1989) showed that in C. pulsatilla Wollenweber, contractile vacuoles are present in freshwater, but only spongiomes are left above salinities of $10 \%$. Spongiomes seem to assist in the rapid formation of contractile vacuoles, which expel excess water from the cell, maintaining proper turgor pressure under hypotonic conditions. This likely makes them important for the survival of Chlamydomonas sp. ARC under the low-salinity conditions associated with melting sea ice. A tough cell wall enables microorganisms to better withstand hypoosmotic shock (Hellebust 1985), which is suggested to be a reason why diatoms are so abundant in sea ice (Arrigo \& Thomas 2004). However, for rapidly growing organisms, the metabolic costs of operating contractile vacuoles are much lower than those of synthesizing a stronger organic cell wall (Raven 1982), which suggests a strategy for fast-growing opportunistic chlorophytes in decaying sea ice.

This research provides insight into the succession of microbial communities in areas seasonally covered by sea ice. High concentrations of Chlamydomonas sp. and other phototrophic flagellates (Weissenberger 1998) in newly formed sea ice suggest that Chlamydomonas sp. ARC could be an important early colonizer of sea ice. As the season progresses, sea-ice communities develop, with diatoms dominating the bottom of the ice and phototrophic dinoflagellates and chrysophytes occupying the upper portion of the ice (Stoecker et al. 1998). In spring and summer, a stable layer of low-salinity and low-density meltwater forms under melting sea ice and provides a transient habitat capable of supporting ephemeral blooms of green algae such as Pyramimonas sp. (Gradinger 1996) and potentially Chlamydomonas sp. ARC. Chlamydomonas sp. ARC was isolated from a bottom segment of an ice core, yet it could also occur in higher portions of the ice or in under-ice meltwater lenses. Our research has shown that its euryhaline and psychrophilic/psychrotolerant nature enables it to survive winter sea-ice conditions and that it can rapidly multiply in melt water and the water column in spring, suggesting a ubiquitous occurrence of this species in polar seas.

Acknowledgements. We thank N. P. A. Hüner for providing a culture of Chlamydomonas raudensis Ettl UWO-241; T. Soule for help with the pigment analysis; and S. Bingham and the DNA sequencing laboratory at ASU for sequencing the investigated strains. F. Garcia-Pichel provided helpful comments on an earlier version of the manuscript. Electron microscopy was done by D. Lowry in the School of Life Sciences Electron Microscopy and Bio-Imaging Facility at Arizona State University. We also thank the Barrow Arctic Research Consortium for their logistical support. And, finally, we thank our anonymous reviewers for their constructive criticism.

\section{LITERATURE CITED}

Aletsee L, Jahnke J (1992) Growth and productivity of the psychrophilic marine diatoms Thalassiosira antarctica Comber and Nitzschia frigida Grunow in batch cultures at temperatures below the freezing point of sea water. Polar Biol 11:643-647

Arrigo KR (2003) Primary production in sea ice. In: Thomas DN, Dieckmann GS (eds) Sea ice: an introduction to its physics, chemistry, biology and geology. Blackwell Science, Oxford, p 143-183

Arrigo KR, Thomas DN (2004) Large scale importance of sea ice biology in the Southern Ocean. Antarct Sci 16:471-486

Assur A (1958) Composition of sea ice: and its tensile strength. In: National Academy of Sciences (ed) Arctic Sea ice. Publ. 598, National Research Council, Washington, DC, p 106-138

Bartsch A (1989) Die Eisalgenflora des Weddellmeeres (Antarktis): Artenzusammensetzung und Biomasse sowie Ökophysiologie ausgewählter Arten. Ber Polarforsch 63:1-10

Buchheim MA, Lemieux C, Otis C, Gutell RR, Chapman RL, Turmel M (1996) Phylogeny of the Chlamydomonadales (Chlorophyceae): a comparison of ribosomal RNA gene sequences from the nucleus and the chloroplast. Mol Phylogenet Evol 5:391-402

Comiso JC (2003) Large-scale characteristics and variability of the global sea ice cover. In: Thomas DN, Dieckmann GS (eds) Sea ice: an introduction to its physics, chemistry, biology, and geology. Blackwell Science, Oxford, p 112-142

Demmig-Adams B, Adams WW, Ebbert V, Logan BA (1999) Ecophysiology of the xanthophyll cycle. In: Frank HA, Young AJ, Britton G, Cogdell RJ (eds) The photochemistry of carotenoids. Kluwer Academic Publishers, Dordrecht, p 245-269

Dron R, Rahire M, Rochaix JD (1982) Sequence of the chloroplast DNA region of Chlamydomonas reinhardii containing the gene of the large subunit of ribulose bisphosphate carboxylase and parts of its flanking genes. J Mol Biol 162:775-793

Eicken H (2003) From the microscopic, to the macroscopic, to the regional scale: growth, microstructure and properties of sea ice. In: Thomas DN, Dieckmann GS (eds) Sea ice: an introduction to its physics, chemistry, biology and geology. Blackwell Science, Oxford, p 22-81

Ettl H (1976) Die Gattung Chlamydomonas Ehrenberg (Chlamydomonas und die nächstverwandten Gattungen II). Nova Hedwigia Beih 49:1-1122

Gradinger R (1996) Occurrence of an algal bloom under Arctic pack ice. Mar Ecol Prog Ser 131:301-305

Grant WS, Horner RA (1976) Growth responses to salinity variation in four Arctic ice diatoms. J Phycol 12:180-185

Hellebust JA (1985) Mechanisms of response to salinity in halotolerant microalgae. Plant Soil 89:69-81

Hellebust JA, Mérida T, Ahmad I (1989) Operation of contractile vacuoles in the euryhaline green flagellate Chlamydomonas pulsatilla (Chlorophyceae) as a function of salinity. Mar Biol 100:373-379 
Hoham RW, Bonome TA, Martin CW, Leebens-Mack JH (2002) A combined 18s rDNA and rbcL phylogenetic analysis of Chloromonas and Chlamydomonas (Chlorophyceae, Volvocales) emphasizing snow and other coldtemperature habitats. J Phycol 38:1058-1064

Horner RA (1985) Sea ice biota. CRC Press, Boca Raton, FL

Kaczmarska I, Jahn R (2006) Taxanomic appraisal of Melosira arctica Dickie and description of a new variety (Bacillariophyta). Bot Mar 49:151-164

Köst HP (1988) Plant pigments: fat soluble pigments. In: Zweig G, Sherma J (eds) CRC handbook of chromatography, Vol 1. CRC Press, Boca Raton, FL

Krembs C, Gradinger R, Spindler M (2000) Implications of brine channel geometry and surface area for the interaction of sympagic organisms in Arctic sea ice. J Exp Mar Biol Ecol 243:55-80

Kumar S, Tamura K, Nei M (2004) MEGA3: integrated software for molecular evolutionary genetics analysis and sequence alignment. Briefing in Bioinformatics 5:150-163

Leya T (2004) Feldstudien und genetische Untersuchungen zur Kryophilie der Schneealgen Nordwestspitzbergens. $\mathrm{PhD}$ dissertation, Humboldt-Universität zu Berlin

Liu C, Huang X, Wang X, Zhang X, Li G (2006) Phylogenetic studies on two strains of Antarctic ice algae based on morphological and molecular characteristics. Phycologia 45:190-198

Lizotte MP (2003) The microbiology of sea-ice. In: Thomas DN, Dieckmann GS (eds) Sea ice: an introduction to its physics, chemistry, biology, and geology. Blackwell Science, Oxford, p 184-210

Maxwell DP, Falk S, Trick CG, Huner NPA (1994) Growth at low temperature mimics high-light acclimation in Chlorella vulgaris. Plant Physiol 105:535-543

Medlin L, Elwood HJ, Stickel S, Sogin ML (1988) The characterization of enzymatically amplified eukaryotic 16S-like rRNA-coding regions. Gene 71:491-499

Morgan RM, Ivanov AG, Priscu JC, Maxwell DP, Hüner NPA (1998) Structure and composition of the photochemical apparatus of the Antarctic green alga, Chlamydomonas subcaudata. Photosynth Res 56:303-314

Morita RY (1975) Psychrophilic bacteria. Bacteriol Rev 39: $144-167$

Editorial responsibility: Alain Vézina,

Dartmouth, Nova Scotia, Canada
Nei M, Kumar S (2000) Molecular evolution and phylogenetics. Oxford University Press, New York

Neuer S (1992) Growth dynamics of marine Synechococccus spp. in the Gulf of Alaska. Mar Ecol Prog Ser 83:251-262

Nozaki H, Itoh M, Sano R, Uchida H, Watanabe MM, Kuroiwa $T$ (1995) Phylogenetic relationships within the colonial Volvocales (Chlorophyta) inferred from rbcL gene sequence data. J Phycol 31:970-979

Nozaki H, Onishi K, Morita E (2002) Differences in pyrenoid morphology are correlated with differences in the $r b c L$ genes of members of the Chloromonas lineage (Volvocales, Chlorophyta). J Mol Evol 55:414-430

Pocock T, Lachance MA, Pröschold T, Priscu JC, Kim SS, Hüner NPA (2004) Identification of a psychrophilic green alga from Lake Bonney Antarctica: Chlamydomonas raudensis Ettl. (UWO 241) Chlorophyceae. J Phycol 40: $1138-1148$

Pröschold T, Birger M, Schlösser UG, Melkonian M (2001) Molecular phylogeny and taxonomic revision of Chlamydomonas (Chlorophyta). I. Emendation of Chlamydomonas Ehrenberg and Chloromonas Gobi, and description of Oogamochlamys gen. nov. and Lobochlamys gen. nov. Protist 152:265-300

Raven J (1982) The energetics of freshwater algae; energy requirements for biosynthesis and volume regulation. New Phytol 92:1-20

Rowan K (1989) Photosynthetic pigments of algae. Cambridge University Press, Cambridge

Soule T, Stout V, Swingley WD, Meeks JC, Garcia-Pichel F (2007) Molecular genetics and genomic analysis of scytonemin biosynthesis in Nostoc punctiforme ATCC 29133. J Bacteriol 189:4465-4472, doi: 10.1128/JB.01816-06

Stoecker DK, Gustafson DE, Black MMD, Baier CT (1998) Population dynamics of microalgae in the upper land-fast sea ice at a snow-free location. J Phycol 34:60-69

Szyszka B, Ivanoff AG, Hüner NPA (2007) Psychrophily is associated with differential energy partitioning, photosystem stoichiometry and polypeptide phosphorylation in Chlamydomonas raudensis. Biochim Biophys Acta 1767:789-800, doi: 10.1016/j.bbabio.2006.12.001

Weissenberger J (1998) Arctic sea ice biota: design and evaluation of a mesocosm experiment. Polar Biol 19:151-159

Submitted: April 7, 2007; Accepted: September 7, 2007

Proofs received from author(s): January 25, 2008 